Neuro Images

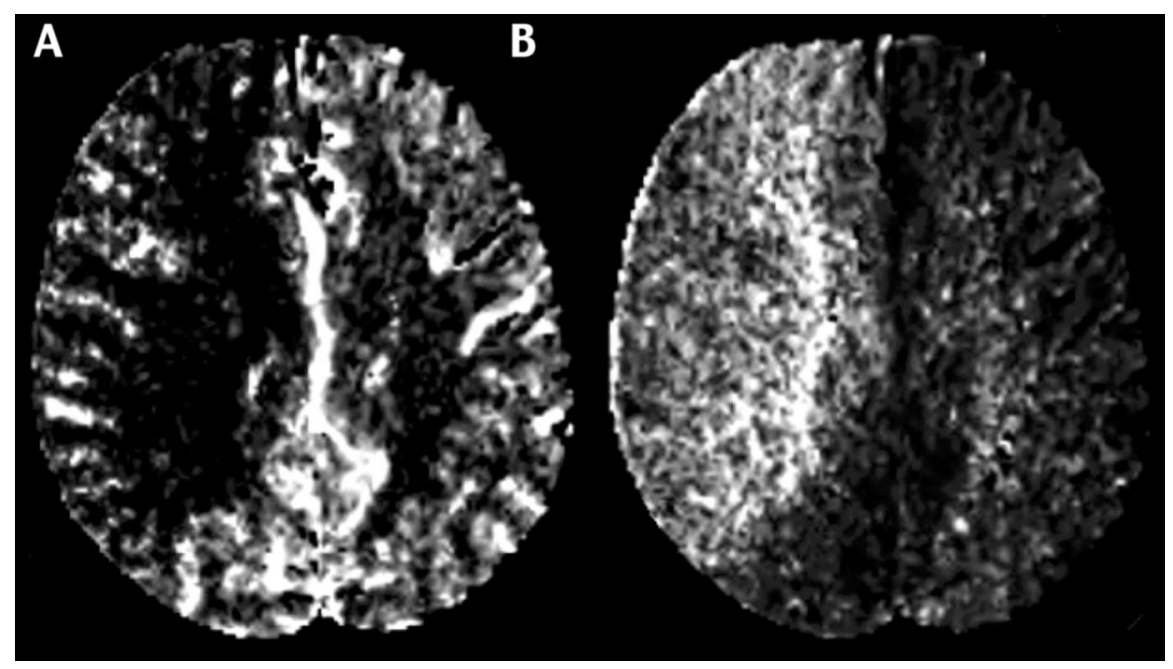

Figure. CT perfusion study. Cerebral blood flow map showing severely decreased flow over the right hemisphere; around $20 \mathrm{~mL} / 100 \mathrm{~g} / \mathrm{min}$ (A) at worst (compared with $35 \mathrm{~mL} / 100 \mathrm{~g} / \mathrm{min}$ over the left hemisphere). (B) Mean transit time (MTT) map with a prolonged MTT of 6 seconds.

\section{Syncope and cerebral hypoperfusion}

Shelagh B. Coutts, MBChB; William Hu, MD; and Michael D. Hill, $M D$

An 87-year-old woman who had had a right middle cerebral

From the Departments of Clinical Neurosciences (Drs. Coutts, Hu, and Hill) and Radiology (Dr. Hu), University of Calgary, Seaman Family MR Centre (Dr. Coutts), Departments of Medicine and Community Health Sciences (Dr. Hill), Foothills Medical Centre, Calgary, Alberta, Canada.

Received December 2, 2002. Accepted in final form February 21, 2003.

Address correspondence and reprint requests to Dr. Shelagh Coutts, Seaman Family MR Centre, Foothills Hospital, 1403 29th St. NW, Calgary, Alberta T2N 2T9, Canada; e-mail: shelagh.coutts@calgaryhealthregion.ca artery stroke 2 years previously was admitted following multiple syncopal episodes. The episodes occurred only on standing and caused a mild left hemiparesis, which resolved gradually on lying down. Blood pressure showed a $30-\mathrm{mm} \mathrm{Hg}$ postural drop. Cardiac and EEG monitoring was normal. Carotid CT angiography and Doppler ultrasound showed an occluded right common carotid artery with retrograde external carotid artery flow supplying the right internal carotid artery. Brain CT and MRI showed evidence of moderate leukoariosis, but no evidence of prior infarction. The patient was asymptomatic during a CT perfusion study (figure), which showed critical hypoperfusion of her right hemisphere estimated at $20 \mathrm{~mL} / 100 \mathrm{~g} / \mathrm{min}$ (figure, A). She was successfully treated with fludrocortisone and compression stockings. 


\section{Neurology}

Syncope and cerebral hypoperfusion

Shelagh B. Coutts, William Hu and Michael D. Hill

Neurology 2003;60;2011

DOI 10.1212/01.WNL.0000068018.95076.C0

This information is current as of June 24, 2003

\section{Updated Information \& Services}

\section{Subspecialty Collections}

\section{Permissions \& Licensing}

\section{Reprints}

including high resolution figures, can be found at: http://n.neurology.org/content/60/12/2011.full

This article, along with others on similar topics, appears in the following collection(s):

\section{All Cerebrovascular disease/Stroke}

http://n.neurology.org/cgi/collection/all_cerebrovascular_disease_strok e

All Imaging

http://n.neurology.org/cgi/collection/all_imaging

Cardiac

http://n.neurology.org/cgi/collection/cardiac

\section{CT}

http://n.neurology.org/cgi/collection/ct

MRI

http://n.neurology.org/cgi/collection/mri

Information about reproducing this article in parts (figures,tables) or in its entirety can be found online at:

http://www.neurology.org/about/about_the_journal\#permissions

Information about ordering reprints can be found online: http://n.neurology.org/subscribers/advertise

Neurology ${ }^{\circledR}$ is the official journal of the American Academy of Neurology. Published continuously since 1951, it is now a weekly with 48 issues per year. Copyright . All rights reserved. Print ISSN: 0028-3878. Online ISSN: 1526-632X.

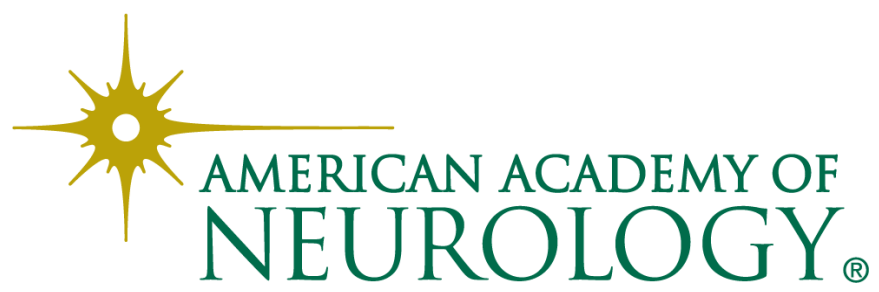

